\title{
Hak Menguasai Negara Terhadap Pengadaan Tanah Untuk Perkebunan Kelapa Sawit Oleh Pemerintah Daerah Kepada Pihak Ketiga
}

\author{
K. Kariadi \\ Fakultas Hukum, Universitas Muhammadiyah Sorong \\ Email : Kariadipakkar@gmail.com
}

\begin{abstract}
Abstrak
Penelitian ini bertujuan untuk mengetahui, menganalisis dan menjelaskan kewenangan dan kekuasaan yang dimiliki oleh Pemerintah sebagai lembaga Negara yang berwenang mengurusi tentang tanah. Tanah merupakan obyek yang urgen dalam kehidupan bermasyarakat, berbangsa dan bernegara. Berdasarkan penelitian dan Pembahasan, maka penulis Perkembangan tidak akan terlepas dari pertumbuhan dan perubahan yang terjadi dimasyarakat. Pertumbuhan dalam bidang industri dan perkebunan kelapa sawit akan mengubah tatanan sosial atau nilai-nilai sosial yang ada dalam masyarakat dan tidak sedikit berujung kepada konflik. Perubahan tingkahlaku (behavior) para aparatur Negara yang seharusnya menjadi "bapak yang baik" buat masyarakatnya malah melakukan tindakan diskriminasi, lebih mengutamakan pemilik modal disebabkan kurangnya pengamalan dan pemahaman tentang nilai-nilai Pancasila dan Konstitusi. Hak menguasai negara dalam pengelolaan sumberdaya alam, bumi, air, dan ruang angkasa serta kekayan alam yang terkandung didalamnya, dikelolah secara holisme yang menyeluruh dalam artian memberikan pengelolaan dengan memperhatikan manfaat buat alam dan manusia, serta diperuntukan sebesar-besarnya kemakmuran dan kesejahteraan rakyat secara kolektif tanpa adanya diskriminasi terhadap golongan atau kelompok tertentu, "menganak emaskan" pemilik modal.
\end{abstract}

Kata Kunci : Hak Menguasai Negara; Tanah; Sosiologi Hukum

\section{PENDAHULUAN}

Kebutuhan manusia akan tanah tidak hanya dikenal pada masa sekarang tetapi sejak manusia diciptakan oleh Allah SWT dan ditempatkan di bumi. Tanah merupakan sarana dan kebutuhan yang amat penting bagi kehidupan manusia. Kekayaan paling utama yang dimiliki oleh masyarakat, terkhusus masyarakat adat adalah tanah. Sehingga tanah merupakan salah satu harta pusaka yang dimiliki oleh masyarakat adat, yang pengelolaannya diserahkan kepada tiap-tiap masyarakat adat. Tanah dalam masyarakat adat tidak hanya mempunyai nilai-nilai ekonomis tetapi juga nilai-nilai magis-spritual. Kehidupan modern tanah tetap menjadi bagian yang vital, disebabkan kebutuhan manusia akan tanah sangat banyak, segala sendi perekonomian membutuhkan sebagai tempat untuk melakukan usaha. Bahkan ketika manusia telah meninggal membutuhkan tanah sebagai tempat "peristirahatan".

Kehidupan masyarakat yang dinamis, selalu mengalami perubahan-perubahan sejalan dengan perkembangan dibidang ekonomi, sosial, dan politik, mengakibatkan kebutuhan masyarakat akan tanah mengalami perkembangan. Perkembangan merupakan perpaduan antara perubahan dan pertumbuhan. Pertumbuhan ekonomi dan perubahan paradigma berfikir akan menimbulkan suatu penilaian tersendiri tentang tanah. Tanah akan menjadi komoditi 
ekonomi karena merupakan salah satu intrumen penting dalam pembangunan sebuah industri tidak terkecuali dibidang perkebunan kelapa sawit.

Urgensitas tanah dalam kehidupan bermasyarakat, mengharuskan Negara untuk membuat suatu regulasi yang mengatur tentang tanah. Regulasi atau peraturan akan mengatur tentang kepentingan-kepentingan masyarakat yang menyangkut tentang tanah. Dalam perkembangannya, mengingat kebutuhan rakyat untuk mensejahterakan kehidupannya semakin mendesak dan semakin kompleks, memperkenankan Negara untuk lebih aktif dalam mengurus kesejahteraan rakyatnya yang biasa disebut negara hukum kemakmuran atau negara kesejahteraan.

Negara kemakmuran atau negara kesejahteraan campur tangan negara dalam menciptakan suatu industri yang berkeadilan sosial untuk kesejahteraan merupakan kebijakan pembangunan Nasional. Industrialisasi sebagai kebijakan pembangunan Nasional, sering diartikan tidak sekedar maknanya sebagai program dan kebijakan umum. Bahkan industrialisasi menjadi sebuah ideologi yang menuntun dan menuntut pembangunan secara berangsur tetapi pasti. Industrialisasi sebagai kebijakan pembangunan Nasional mempunyai peran penting dalam memberikan kemakmuran dan kesejahteraan rakyat sesuai dengan idiologi bangsa. Kesejahteraan yang merata dirasakan oleh seluruh rakyat, tanpa mengenal status sosial dan kedudukan, tanpa mengenal pemilik modal/pengusaha dengan rakyat biasa, diperlakukan sama. Kesejahteraan akan berbanding lurus dengan perubahan dan perkembangan dalam masyarakat.

Industrialisasi melahirkan perubahan sosial yang menyangkut sistem nilai, norma, perilaku, organisasi, lembaga sosial, stratifikasi, kekuasaan, interaksi sosial, dan sebagainya. Industrialisasi berpengaruh terhadap pemilikan dan pola penguasaan tanah, intensitas transaksi tanah, pola hubungan kerja dan pendapatan pertanian di pedesaan. Hadirnya berbagai industri diberbagai lokasi, melahirkan komunitas warga yang secara geografis tinggal di sekitar industri, penyesuaian dengan suasana baru dalam artian munculnya industri di tengah masyarakat. Industri yang bergerak dibidang lingkungan dalam hal pemanfaatan lahan tentunya akan memunculkan polemik baru ditengah masyarakat seperti penyediaan lahan. Lahan atau tanah yang merupakan instrumen pokok pendirian sebuah industri semakin hari mengalami penyempitan disebabkan penggunaan akan tanah mengalami peningkatan.

Pemanfaatan tanah yang makin intens untuk tujuan sebagai prioritas pembangunan Nasional, menyebabkan perubahan sosial, misalnya perubahan pola interaksi sosial dalam kaitannya dengan penguasaan, pemilikan, penggunaan, dan pemanfaatan tanah. Perubahan yang terjadi dalam lingkungan masyarakat akan menyebabkan keberadaan UUPA 1960 
dihadapkan pada perkembangan sosial, ekonomi, dan politik yang berbeda dengan realitas sosial saat UUPA 1960 dibentuk. Beberapa realitas sosial yang ada dan mendasari pembentukan UUPA : 1. Nilai kebersamaan atau gotong-royong yang kemudian menjadi pilihan dasar dari setiap usaha di bidang keagrariaan, 2. Pengaruh hukum adat dalam penetapan prinsip atau asas-asasnya kerena hukum adat masih hidup dan berlaku dalam masyarakat, 3 . Ciri kehidupan masyarakat yang bersifat agraris yang mewarnai orientasi ketentuan-ketentuan dan tujuannya yakni peningkatan kesejahteraan petani, 4. Kondisi politik pemerintah yang masih memerlukan penanganan secara sentralistis yang kemudian mewarnai pelaksanaan kewenangan dari hak menguasai negara.

Undang-Undang Dasar Negara Republik Indonesia 1945 Pasal 33 ayat 3 memberikan suatu pedoman dalam pemanfaatan sumberdaya alam, yaitu digunakan sebesar-besarnya untuk kemakmuran rakyat. Negara mempunyai andil besar dalam memberikan kemakmuran dan kesejahteraan buat rakyatnya dengan cara membuat suatu regulasi yang pro terhadap kepentingan masyarakat. Negara berdasarkan Undang-Undang mempunyai kewenangan mengatur tanah digunakan untuk kemakmuran rakyat. Nilai-nilai yang terkandung dalam Pancasila dan Undang-Undang Dasar mengamanatkan kepada pemerintah untuk mengelolah sumberdaya alam, bumi, air, dan kekayaan alam sebesar-besarnya kemakmuran rakyat.

Tanah sebagai instrumen utama untuk pembangunan, berkonsekuensi tanah yang ada dikawasan Negara menjadi kian terkontrol dan jatuh kepenguasaan Negara untuk kepentingan pembangunan. Peraturan mengenai pertanahan yang sangat dikuasai paradigma teritorialisme dan dikuatkan oleh ideologi "developmentalisme" atau "pembangunanisme", mejadikan hukum pertanahan tidak mungkin bersifat populis. Developmentalisme atau pembangunanisme lebih bersifat kewataknya yang etis sehingga selalu melahirkan marjinalisasi di pihak petani tradisional yang notabene adalah pemilik-pemilik tanah. Pemerintah dengan klausula "demi kepentingan umum" yang dikemas dalam peraturan-peraturan pertanahan menjadi "linta" mengambil dan tidak jarang mengusir pemilik-pemilik modal kecil dari tanahnya sendiri. Pemerintah lebih mengutamakan pemilik modal/ pengusaha untuk menfaatkan atau mengelolah sumberdaya alam, menyebabkan kesenjangan dalam mencapai kemakmuran dan kesejahteraan. Pemilik modal makin kaya, sedang petani makin miskin bahkan menjadi buruh dilahannya sendiri.

Pembangunan nasional diberbagai bidang tidak terkecuali perkebunan kelapa sawit akan menimbulkan berbagai problematika dalam kehidupan. Tanah sebagai instrumen pokok dalam pembangunan semakin hari mengalami keterbatasan dalam kepemilikannya. Memunculkan perilaku melanggar hukum dari pemerintah. Pemerintah sebagai "bapak yang baik" 
mengutamakan kepentingan rakyat dalam hal menciptakan kesejahteraan bagi seluruh rakyat Indonesia. Dalam kenyataan pemerintah lebih mengutamakan pemilik modal dan pengusaha dalam pemanfaatan lahan. Pemerintah dengan menggunakan hak menguasai Negara merampas hak masyarakat, serta memberikannya kepada pemilik modal atau pengusaha.

Cita-cita yang tertanam dalam Pasal 33 UUD 1945 ialah produksi yang besar-besar sedapat-dapatnya dilaksanakan oleh pemerintah dengan bantuan pinjaman dari luar. Apabila siasat ini tidak berhasil, perlu juga diberikan kesempatan kepada pengusaha menanam modalnya di Indonesia dengan syarat yang ditentukan oleh pemerintah. Syarat itu terutama menjamin kekayaan alam seperti hutan dan kesuburan tanah, air kita tetap terpelihara. Ketentuan dibenarkan untuk melakukan investasi di bidang sumber daya alam untuk mewujudkan kesejahteraan sosial. Terlibatnya pengusaha atau pemilik modal untuk melakukan pengelolaan sumberdaya alam mendapat legitimasi oleh UUD 1945 dengan syarat pengelolaan tersebut tidak mengubah kesuburan tanah dan yang lebih pokok memberikan kesejahteraan masyarakat secara merata.

Pengelolaan lahan yang dijadikan sebagai perkebunan kelapa sawit mempunyai dampak dilingkungan warga atau komunitas, fungsi sosial dalam teks normatif- positivistik dikaji dalam konteks sosial yakni masyarakat/ komunitas yang lokasi keberadaannya di sekitar industri. Dalam berbagai studi yang pernah dilakukan, masyarakat yang demikian sarat dengan permasalahan tanah. Studi Mather misalnya, menyebutkan kehadiran industri di pedesaan di samping berfungsi sebagai sumber akumulasi baru bagi para pemimpin desa juga memungkinkan para pemimpin desa untuk mencari komisi sebagai perantara dalam pembebasan tanah, maupun memperoleh penghasilan tambahan dengan menyewa kamar.

Studi yang dilakukan oleh Mather terjadi pula di konawe utara dimana pemerintah (Bupati, camat sampai pada tingkat desa) dengan menggunakan "kekuasaan" melakukan pemaksaan kepada masyarakat, untuk menerima kehadiran PT DJL ditengah masyarakat serta menyerahkan pengelolaan tanahnya untuk perkebunan kelapa sawit. Pemerintah (camat dan kepala desa) dengan "kekuasaannya" membuat surat keterangan tanah tanpa sepengetahuan masyarakat pemilik lahan. Surat keterangan tanah akan dijadikan alas hak oleh pemilik modal atau PT DJL untuk menebang dan membersihkan pohon yang ada diatas tanah tersebut. Ironisnya pembersihan lahan dan penebangan tanpa pemberian ganti kerugian sepersenpun atas tanaman masyarakat. Pemerintah (camat dan kepala-kepala desa) mendapatkan komisi dari penyetoran surat keterangan tanah. Pemerintah dengan menggunakan kekuasaannya melakukan pemaksaan kepada masyarakat untuk menandatangani MoU kerjasama antara PT DJL dengan masyarakat, tanpa adanya transparansi penjelasan isi dari MoU tersebut, menurut 
pihak PT DJL dan pemerintah akan memberikan kesejahteraan dan kemakmuran bagi masyarakat. Dengan bergulirnya waktu ternyata MoU tersebut sangat merugikan masyarakat disebabkan salah satu pasal dalam MoU. Pemerintah seharusnya sebagai "bapak yang baik" memberikan suatu kontribusi yang positif buat masyarakatnya dalam artian pemberian kesejahteraan yang adil dan merata, sebagaimana amanat Pancasila dan konstitusi. Pada kenyataan pemerintah dengan mengunakan Hak Menguasai Negara, yang dijadikan oleh para aparat Negara untuk melakukan penindasan kepada rakyatnya. Penerapan nilai Idiologi Pancasila dan Konstitusi dalam menjalankan tugas dan fungsinya para aparatur negara masih jauh dari kata ideal. Berdasarkan uraian latar belakang di atas maka penulis mengambil suatu rumusan masalah sebagai berikut; (a) Bagaimanakah Hak Menguasai Negara dalam pengadaan lahan perkebunan kelapa sawit pada lahan masyarakat dalam tinjauan sosiologi hukum?

\section{PEMBAHASAN}

\section{Kasus posisi (Kongkalikong Pemerintah dan PT DJL dalam Pengadaan Lahan Perkebunan Kelapa Sawit pada Lahan Masyarakat di Kabupaten Konawe Utara)}

Tahun 2004, PT Damai Jaya Lestari (DJL) mengantongi surat rekomendasi Bupati Konawe, Lukman Abunawas. Surat rekomendasi itu perihal sosialisasi rencana keberadaan PT DJL. Prakteknya, Pihak perusahaan PT DJL tidak sekedar melakukan sosialisasi keberadaan perusahaan, tetapi sudah mulai masuk dalam proses pengambilan lahan/tanah rakyat dibantu oleh pihak camat Asera saat itu, H. Abu Haera dan para kepala desa yang berada diwilayah wiwirano.

Kepala Desa menerbitkan surat keterangan tanah (SKT) disetiap desa kepemimpinannya. SKT tersebut lalu diserahkan kepada pihak PT DJL sebagai alat hukum untuk melakukan penanaman kelapa sawit tanpa pengetahuan pemilik tanah. Proses penyerahan tanah hanya dilakukan oleh pihak pemerintah kecamatan dan pihak kepala desa tanpa melibatkan masyarakat pemilik tanah. Masyarkat dipaksa menerimah kehadiran PT. DJL, sementara SKT tersebut menunjukkan seolah-olah kehadiran PT. DJL atas permintaan masyarakat setempat, spekulasi kejadian tersebut didalangi oleh camat dan kepala-kepala desa.

Penyerahan surat keterangan tanah yang dilakukan oleh pihak camat dan kepala desa menjadi landasan bagi PT. DJL untuk melakukan pembersihan (penebangan tanaman tumbuh yang ada diatas lahan/tanah tersebut) tanpa proses ganti rugi tanaman tumbuh masyarakat. PT DJL melakukan sosialisasi terkait MoU (perjanjian kemitraan antara PT. DJL dan petani pemilik lahan sawit). Sosialisasi yang dilakukan tidak transparan hanya menunjukkan seolaholah kehadiran PT DJL akan membawa kesejahteraan masyarakat. Proses penandatanganan 
MoU melalui mekanisme pemaksaan oleh kepala desa dengan warga yang memiliki lahan. Warga yang belum menandatangani MoU diminta untuk datang ke kantor PT DJL untuk menandatangani MoU tersebut.

Masyarakat pemilik lahan/tanah terbuai dengan iming-iming keuntungan bagi hasil yang tertuang dalam MoU, yakni dengan bagi hasil 60 : 40. Faktanya petani hanya mendapatkan Rp $50.000,00$ per hektar tiap bulannya. Sumber masalah dari minimnya bagi hasil yang diterimah petani tersebut ternyata diakibatkan oleh adanya pasal-pasal dalam MoU yang merugikan petani, khususnya pasal 3 ayat 3 dalam MoU, yang mewajibkan petani menanggung $40 \%$ biaya produksi atau biaya eksploitasi.

Pasal 3 MoU. Investasi untuk penanaman kelapa sawit sampai produksi adalah sebesar Rp 24.000.000,00 (dua puluh empat juta rupiah) perhektar dengan ketentuan sebagai berikut; (a) Pihak pertama menanggung 60\% (enam puluh) persen biaya investasi tersebut diatas atau sebesar Rp 14.400.000,00 (empat belas empat ratus ribu rupiah); (b) Pihak kedua menanggung $40 \%$ (empat puluh) persen dari biaya investasi tersebut diatas sebesar Rp. 9.600.000,00 (sembilan juta enam ratus ribu rupiah); (c) Biaya persertifikatan tanah Rp. 1.000.000, (satu juta rupiah) per persil bagi tanah yang belum bersertifikat; (d) Biaya eksploitasi/biaya produksi tanaman menghasilkan adalah; (1) Biaya memelihara tanaman; (2) Biaya panen dan Pengangkutan ke pabrik; (3) Biaya umum kebun; (4) Pemeliharaan Mesin-mesin; (5) Bahan bakar minyak

Dengan ketentuan : (a) Pihak pertama menanggung 60\% (enam puluh) persen dari bahaya eksploitasi/biaya produksi tanaman menghasilkan tersebut.; (b) Pihak kedua menanggung 40\% (empat puluh) persen dari biaya eksploitasi/biaya produksi tanaman menghasilkan tersebut diatas.; (c) Biaya eksploitasi tersebut akan dirincikan pada saat pembagian hasil.

\section{Hak Menguasai Negara dalam Pengelolaan Sumberdaya Alam, Bumi, Air, Tanah dan Ruang Angkasa Sebesar - besarnya Untuk Kemakmuran Rakyat.}

Negara Indonesia merupakan Negara hukum sebagaimana tercantum dalam UUD 1945. Pemerintahan yang berdasarkan atas hukum akan melahirkan adanya jaminan perlindungan terhadap hak-hak dasar masyarakat sehingga kepentingan antara pemerintah yang menjalankan kekuasaan dan rakyat sebagai subyek pemilik negara dapat selalu bersesuaian dan sejalan. Konsep negara hukum menjadi koridor bertindak dan berbuat pemerintah, sekaligus berfungsi sebagai acuan dasar dan patokan penilaian dalam penyelenggaraan pemerintah.

Pasal 33 UUD 1945 mengatur pengelolaan sumberdaya alam, mengandung pesan bahwa terhadap Negara diberikan hak menguasai, oleh Konstitusi untuk memanfaatkan bumi dan air dan kekayaan alam yang terkandung didalamnya untuk sebesar-besar kemakmuran rakyat. 
Mengelolah sumberdaya alam secara rasional dan bijaksana untuk memenuhi kebutuhan generasi sekarang dengan meningkatkan kebutuhan generasi yang akan datang. Pembangunan berkelanjutan adalah bahwa pembangunan berkelanjutan tidak hanya mengandung makna keadilan antargenerasi, tetapi juga makna dan sikap yang holism, yaitu sikap yang menempatkan manusia bersama alam. Eratnya hubungan manusia dengan alamnya, menjadikan makna yang paling hakiki dari pengertian pembangunan berkelanjutan. Strategi pembangunan berkelanjutan harus mengembangkan keselarasan antar umat manusia dan antar manusia dengan alam.

Manusia dan alam merupakan komponen yang tidak bisa dipisahkan, pengelolaan sumberdaya alam hendaklah memperhatikan hubungan keterkaitan manusia dan alam. Tanah merupakan bagian dari alam menjadi salah satu instrumen penting dalam pembangunan industri. Negara Indonesia merupakan negara berkembang yang akan mengalami perubahan dan pertumbuhan tentunya, akan melakukan pembangunan diberbagai bidang yang dapat menopang perekonomian bangsa, serta memberikan kesejahteraan bagi masyarakat. Pembangunan merupakan suatu proses perubahan yang terencana terhadap kondisi sosial, budaya, dan lingkungan. Pembangunan dilakukan untuk menjangkau keseimbangan pengetahuan yang ada pada seluruh anggota masyarakat yang hidup dalam satu lingkungan yang sama sehingga tercipta pengetahuan yang sama/mirip terhadap masing-masingnya dan juga terhadap lingkungan hidup.

Asas pembangunan yang mendasarkan pada prinsip pembangunan berkelanjutan yang berwawasan lingkungan hidup menempatkan sumber daya alam dan lingkungan hidup sebagai modal pertumbuhan ekonomi semata tetapi juga sebagai penopang sistem kehidupan. Pemikiran mengenai pembangunan berkelanjutan berintikan pada kesepakatan dua prinsip utama pembangunan, yaitu prinsip pelestarian fungsi lingkungan hidup dan prinsip kesejahteraan rakyat.

Negara mempunyai andil untuk campur tangan dalam memberikan kesejahteraan bagi rakyaknya. Negara kesejahteraan (negara hukum modern) Muchsan menyatakan sebagai berikut: Tujuan pokok negera tidak terletak pada mempertahankan hukum (positif), tetapi pada tujuan menciptakan keadilan sosial (sociale gerechtigheid) bagi semua warga negara. Oleh karena itu jika perlu, negara dapat bertindak diluar hukum untuk mencapai keadilan sosial bagi seluruh warga negara. Alat administrasi negara dalam melaksanakan fungsinya diberi kebebasan untuk bertindak tanpa harus melanggar norma hukum dan bertindak sewenangwenang. 
Konsep negara kesejahteraan menurut Bagir Manan, adalah negara atau pemerintah yang tidak semata-mata sebagai penjaga keamanan atau ketertiban masyarakat tetapi juga sebagai pemikul utama tanggung jawab dalam mewujudkan keadilan sosial, kesejahteraan umum, dan sebesar-besarnya kemakmuran rakyat.

Berdasarkan konsep negara kesejahteraan, negara mempunyai andil besar dalam pengelolaan sumberdaya alam, air, bumi, dan ruang angkasa yang bertujuan untuk memberikan kesejahteraan bagi seluruh rakyat Indonesia bukan kepada individu atau kelompok yang mempunyai modal. Negara sebagai "bapak yang baik" berlaku adil dalam melakukan pemanfaatan sumberdaya alam, pengelolaan sumberdaya alam memperhatikan keterkaitan manusia dan alam. Pengelolaan tidak mendominasi antara satu dan yang lainnya maksudnya, pengelolaan sumberdaya alam hanya memberikan manfaat kepada manusia tetapi merusak ekosistem tumbuhan, merusak kesuburan tanah serta termaksud pula pemanfaatan sumberdaya alam hanya untuk memberikan kesejahteraan buat kalangan tertentu (pemilik modal). Pembangunan merupakan suatu proses perubahan yang terencana terhadap kondisi sosial, budaya, dan lingkungan. Pembangunan dilakukan untuk menjangkau keseimbangan pengetahuan yang ada pada seluruh anggota masyarakat yang hidup dalam satu lingkungan yang sama sehingga tercipta pengetahuan yang sama/mirip terhadap masing-masingnya dan juga terhadap lingkungan hidup. Sebagaimana amanat dari Undang-Undang Dasar untuk menciptakan kesejahteraan yang merata bagi seluruh rakyat Indonesia.

Negara hukum Indonesia yang berdasarkan Pancasila dan UUD 1945 ada keseimbangan dan keterpaduan antara fungsi reguler dan fungsi pembangunan. Keterpaduan kedua fungsi tersebut menyebabkan kewajiban negara Indonesia terhadap rakyatnya menjadi semakin luas, di mana Negara mempunyai kewenangan untuk mengatur dan mengarahkan segala aspek kehidupan masyarakat untuk mewujudkan keadilan sosial bagi seluruh rakyat Indonesia. Pengelolaan sumberdaya alam untuk mewujudkan keadilan sosial merupakan amanat dari idiologi bangsa Indonesia. Amanat tersebut diembankan kepada pemerintah untuk melakukan fungsinya dalam hal menguasai negara atas bumi, air, dan ruang angkasa untuk menciptakan kesejahteraan yang kolektif.

Pancasila sebagai satu kesatuan bulat, adanya norma atau kaidah dalam ketentuan dalam UUPA perihal konsepsi hak menguasai negara (HMN) atas bumi, air, dan kekayaan alam yang terkandung di dalamnya termasuk pemanfaatan ruang angkasa, maka dapat disebut bahwa politik hukum pengelolaan sumberdaya alam Indonesia menggariskan prinsip-prinsip sebagai berikut; (a) Masyarakat dan bangsa Indonesia mengakui adanya hubungan magis-religius antara penduduk, masyarakat, tanah dan lingkungan tempat hidupnya (prinsip kerohanian),; (b) 
Masyarakat dan bangsa Indonesia mengakui dan menyadari arti penting tanah, air dan sumber daya alam yang terkandung di dalamnya disediakan Tuhan bagi segenap masyarakat dan bangsa Indonesia (kebangsaan/nasionalisme),; (c) Tanah, air dan sumberdaya alam yang terkandung di dalamnya untuk seluruh bangsa pemanfaatannya untuk sebesar-besarnya kemakmuran rakyat. (prinsip keadilan sosila),; (d) Negara mempunyai hak menguasai atas bumi, air, dan kekayaan alam yang terkandung didalamnya termaksud pemanfaatan ruang angkasa. Kewenangan negara berupa pengaturan dan penyelenggaran hak menguasai negara atas bumi, air, dan kekayaan alam yang terkandung di dalamnya. Hak menguasai negara berserta kewenangan turunannya diperuntukan bagi sebesar-besarnya kemakmuran rakyat (prinsip demokrasi ekonomi).; (e) Pengelolaan (pemanfaatan) sumberdaya alam menghindari diskriminasi dan pembedaan diantara semua masyarakat Indonesia (prinsip toleransi dan solidaritas).

Berdasarkan kelima sila dalam Pancasila diatas dapat disimpulkan bahwa sumberdaya alam bumi, air, dan kekayaan alam yang terkandung didalamnya serta ruang angkasa dikelolah oleh Negara sebagai pemangku kekuasaan dengan memperhatikan nilai-nilai religius serta bertujuan untuk memberikan sebesar-besarnya untuk kesejahteraan kepada seluruh masyarakat tanpa adanya diskriminasi, tanpa membedakan antara rakyat biasa dan pemilik modal.

Pasal 33 UUD 1945 mengatur pengelolaan sumberdaya alam, mengandung pesan bahwa terhadap Negara diberikan hak menguasai oleh konstitusi untuk memanfaatkan bumi, air, dan kekayaan alam yang terkandung didalamnya untuk sebesar-besar kemakmuran rakyat. Dari ketentuan ini lahir konsep khas bangsa dan sistem ketatanegaraan Indonesia, yakni: Konsep hak menguasai negara (konsep HAM.)

Konsep hak menguasai negara ini diimplementasikan dalam Undang-Undang Nomor 5 Tahun 1960 tentang Pokok-pokok Agraria (UUPA). Dalam ketentuan Pasal 1 ayat (1) UUPA diatur ketentuan:

"atas dasar ketentuan dalam Pasal 33 ayat 3 Undang-Undang Dasar dan hal-hal sebagaimana yang dimaksud dalam Pasal 1, bumi, air dan ruang angkasa, termasuk kekayaan alam yang terkandung didalamnya itu pada tingkat tertinggi dikuasai oleh negara, sebagai organisasi seluruh rakyat."

Bagir manan memaknai ketentuan Pasal 33 ayat (3) UUD 1945 dengan dua aspek kaidah yang terkandung didalamnya yaitu kaidah "hak menguasai negara" dan kaidah “dipergunakan sebesar-besar kemakmuran rakyat" kedua aspek kaidah tersebut tidak dapat dipisahkan satu dengan yang lain, karena keduanya merupakan satu kesatuan sistemik. "Hak menguasai negara merupakan instrumen (bersifat isntrumental), sedangkan "dipergunakan untuk sebesar-besar kemakmuran rakyat, "merupakan tujuan (objectives). 
Keterkaitan antara kaidah "hak menguasai negara" dengan "sebesar-besarnya kemakmuran rakyat" menimbulkan kewajiban negara sebagai berikut: (1) Segala bentuk pemanfaatan bumi, air, ruang angkasa, dan kekayaan alam yang terkandung di dalamnya, harus secara nyata dapat meningkatkan kemakmuran dan kesejahteraan masyarakat.; (2) Melindungi dan menjamin segala hak-hak rakyat yang terdapat di dalam dan di atas bumi, air, ruang angkasa, dan kekayaan alam yang terkandung di dalamnya, dapat dihasilkan secara langsung atau dinikmati langsung oleh rakyat.; (3) Mencegah segala tindakan dari pihak mana pun yang akan menyebabkan rakyat tidak mempunyai kesempatan atau akan kehilangan askes terhadap bumi, air, ruang angkasa dan kekayaan alam yang terkandung didalamnya.

Hak menguasai negara oleh UUPA, dijabarkan menjadi tiga kewenangan negara, hal ini terjabar dalam Pasal 1 ayat 2, yang berbunyi : Hak menguasai negara termaksud dalam ayat 1 pasal ini memberikan wewenang untuk : (a) mengatur dan menyelenggarakan peruntukkan, penggunaan, persediaan, dan pemeliharaan bumi, air, dan ruang angkasa tersebut; (b) menentukan dan mengatur hubungan-hubungan hukum antar orang-orang dengan bumi, air, dan ruang angkasa; (c) menentukan dan mengatur hubungan-hubungan hukum antara orangorang dengan perbuatan hukum mengenai bumi, air, ruang angkasa.

Falsafah peraturan perundang-undangan agraria yang mengharuskan bumi, air, serta kekayaan alam yang terkandung di dalamnya dipergunakan sebesar-besarnya untuk kemakmuran rakyat haruslah mengacu pada paradigma pembangunan baru, yaitu; (a) Penghormatan dan perlindungan terhadap hak asasi manusia, antara lain dalam bentuk penghapusan kemiskinan, perluasan lapangan kerja, dan pemerataan pembangunan; (b) Keberlanjutan kapasitas produksi masyarakat; (c) Pemberdayaan masyarakat melalui pengembangan good governance (partisipasi, transparansi, akuntabilitas, dan rule of law).

Tatanan filosofi dan ideologi Negara, Pancasila sebagai Dasar Negara, merupakan kaidah dasar (grundnorm) dalam tata urutan peraturan perundang-undangan Indonesia dan Undang-Undang Dasar sebagai Konstitusi Negara, memberikan penjelasan hak menguasai negara yaitu negara mempunya andil dalam pengelolaan sumberdaya alam bumi, air dan kekayaan alam yang terkandung di dalamnya dan ruang angkasa berdasarkan nilai-nilai religius dan bertujuan untuk memberikan kesejahteraan rakyat secara kolektif tanpa adanya diskriminasi, mengutamakan pemilik modal atau pengusaha. Kewenangan negara membuat pengaturan yang berkaitan dengan kewenangannya mengatur bumi, air, dan ruang angkasa tersebut, tidak dapat didelegasikan kepada organisasi swasta, karena hal yang berkaitan dengan kesejahteraan umum penuh dengan misi pelayana. 


\section{Hak Menguasai Negara dalam pengadaan Lahan atau Tanah Perkebunan Kelapa Sawit pada lahan masyarakat dalam Tinjauan Sosiologi Hukum.}

Tanah adalah permukaan bumi yang dalam penggunaannya meliputi pula tubuh bumi dan air berserta ruang angkasa yang ada di atasnya sebatas diperlukan untuk kepentingan yang langsung dengan penggunaan tanah. Pengertian tentang tanah tersebut menjelasakan semua hak atas tanah mempunyai fungsi sosial, bahwa hak atas tanah termasuk hak milik yang ada pada seseorang atau badan hukum tidak dibenarkan apabila tanahnya digunakan atau tidak digunakan semata-mata untuk kepentingan pribadi (individunya). Terlebih lagi apabila dipergunakan atau tidak dipergunakan tanah tersebut akan menimbulkan kerugian bagi masyarakat luas. Penggunaan tanah disesuaikan dengan keadaannya dan sifat dari haknya sehingga bermanfaat pula bagi masyarakat dan Negara. Pengelolaan tanah dengan mengutamakan kepentingan masyarakat dan kepentingan perseorangan harus saling mengimbangi sehingga pada akhirnya akan tercapai tujuan pokok yaitu kemakmuran, keadilan dan kebahagiaan bagi seluruh rakyat Indonesia.

Fungsi sosial hak milik atas tanah mengandung pengertian atau ide bahwa tanah bukanlah suatu barang komoditas perdagangan meskipun dimungkinkan bahwa tanah yang dipunyai atau dimiliki oleh seseorang atau badan hukum dapat dijual. Tanah dapat pula dikatakan sebagai mekanisme akumulasi modal, sehubungan dengan munculnya pembangunan yang berorientasi pada pertumbuhan ekonomi, sehingga berakibat adanya peminggiran hakhak masyarakat akan tanah. Bahkan pembangunan ekonomi telah mendorong berkembangnya nilai-nilai yang terkait dengan tanah, sehingga tanah hanya dilihat dari segi ekonomisnya semata dan mempatkan tanah sebagai sarana investasi dan spekulasi. Tanah mempunyai fungsi filosofi lebih menekankan pengelolaan tanah secara keseimbangan, yaitu mengolah lahan dengan memperhatikan hubungan manusia dengan alam. Tanah mempunyai fungsi untuk kelangsungan hidup dalam artian tanah dijadikan tempat untuk membangun pemukiman dan tempat sumber pencaharian dan pemenuhan kehidupan.

Kehidupan manusia bersifat dinamis selalu akan mengalami suatu perubahan sejalan dengan perkembangan diberbagai bidang seperti politik, ekonomi, sosial dan teknologi. Perubahan pola kehidupan manusia dalam bermasyarakat atau berkelompok akan mempengaruhi interaksi atau hubungan sosial diantara masyarakat, begitu pula pemanfaatan tentang tanah. Tanah yang merupakan instrumen penting dalam melakukan kegiatan usaha, tidak terkecuali dibidang perkebunan kelapa sawit. Pengelolaan tanah untuk perkebunan kelapa sawit tidak terlepas dari polemik atau konflik. Konflik yang terjadi dalam hal pembebasan lahan atau tanah, dalam prakteknya pembebasan lahan sarat dengan penyalahgunaan kekuasaan 
oleh pemerintah. Terjadi tindakan pemaksaan dan intimidasi dari pemerintah untuk menerima kehadiran perkebunan kelapa sawit ditengah-tengah lingkungan masyarakat. Hadirnya perkebunan kelapa sawit yang mempunyai tujuan untuk memberikan kesejahteraan kepada masyarakat, ternyata menimbulkan masalah ditengah tengah masyarakat, masyarakat jauh dari kata sejahtera, masyarakat pemilik lahan menjadi buruh dilahannya sendiri. Polemik yang terjadi merupakan dampak dari perkembangan yang diskriminasi dan kurangnya pemaahan para apartur pemerintahan tentang nilai-nilai Pancasila dan UUD.

Saham utama dalam sosiologi hukum yaitu masyarakat, perubahan masyarakat akan mempengaruhi hukum yang berlaku dalam masyarakat. Perkembangan yang terjadi akan mempengaruhi pertumbuhan dan perubahan. Pertumbuhan pada bidang industri akan mengubah kehidupan masyarakat serta mengubah fungsi sosial tentang tanah. Tanah akan mengalami degradasi fungsi menjadi fungsi ekonomis dalam hal investasi dan spekulasi.

Faktor esensial dari tanah mengharuskan pemerintah untuk mengatur dan dituangkan dalam perundang-undangan. Negara sebagai "bapak yang baik" mengatur tentang pemanfaatan tanah yang tujuan pokoknya untuk sebesar-besarnya kemakmuran rakyat. Dalam pengelolaan tanah tidak terlepas dari nilai-nilai spritual atau kerohanian yang memberikan keseimbangan antara manusia dan alam. Serta pengelolaan jauh dari diskriminasi atau "menganak emaskan" pemilik modal atau pengusaha.

Hak menguasai negara tidak dapat berdiri sendiri dalam artian negara mempunyai andil untuk campur tangan dalam mengelolah sumberdaya alam, bumi, air dan ruang angkasa tetapi digunakan sebesar-besarnya untuk kemakmuran rakyat, jadi barometer dari pengelolan sumberdaya alam (tanah) yang memberikan kemakmuran rakyat atau masyarakat ditempat pengelolaan sumberdaya alam tersebut. Pengelolaan sumberdaya alam yang hanya memberikan kemakmuran buat kelompok tertentu (pengusaha atau pemilik modal) secara terang-terangan melanggar nilai-nilai pancasila dan Konstitusi bangsa Indonesia. Penyalahgunaan kekuasaan oleh aparatur negara membuktikan bahwa kurangnya pemahaan tentang nilai-nilai Pancasila dalam melaksanakan tugas dan fungsinya.

Secara sosiologis hak menguasai negara dan pengelolaan sebesar-besarnya untuk memberikan kesejahteraan dan kemakmuran saling bersinergi dalam pengelolaan sumberdaya alam, bumi, air dan ruang angkasa. Negara dalam melaksanakan fungsi menguasai dalam melakukan pengelolaan sumberdaya alam dibatasi oleh sebesar-besarnya kemakmuran rakyat. Pemerintah dalam memberikan izin pengelolaan lahan untuk perkebunan kelapa sawit harusnya memberikan kesejahteraan dan kemakmuran buat masyarakat setempat, bukan hanya sekedar janji-janji kesejahteraan dan kemakmuran. 


\section{SIMPULAN}

Perkembangan tidak akan terlepas dari pertumbuhan dan perubahan yang terjadi dimasyarakat. Pertumbuhan dalam bidang industri dan perkebunan kelapa sawit akan mengubah tatanan sosial atau nilai-nilai sosial yang ada dalam masyarakat dan tidak sedikit berujung kepada konflik. Perubahan tingkahlaku (behavior) para aparatur Negara yang seharusnya menjadi "bapak yang baik" buat masyarakatnya malah melakukan tindakan diskriminasi, lebih mengutamakan pemilik modal disebabkan kurangnya pengamalan dan pemahaman tentang nilai-nilai Pancasila dan Konstitusi. Hak menguasai negara dalam pengelolaan sumberdaya alam, bumi, air, dan ruang angkasa serta kekayan alam yang terkandung didalamnya, dikelolah secara holisme yang menyeluruh dalam artian memberikan pengelolaan dengan memperhatikan manfaat buat alam dan manusia, serta diperuntukan sebesar-besarnya kemakmuran dan kesejahteraan rakyat secara kolektif tanpa adanya diskriminasi terhadap golongan atau kelompok tertentu, "menganak emaskan" pemilik modal.

\section{DAFTAR PUSTAKA}

Bagir manan, 1999, Beberapa catatan atas RUU tentang MIGAS, Makalah pada Diskusi Panel RUU Migas, Unpad Bandung , 1996, politik perundang-undangan dalam rangka mengatasi liberalisasi perekonomian, makalah pada seminar antisipasi liberalisasi perekonomian, fakultas hukum UNILA lampung

Djaja diningrat, surna tjahja, 2005, sustainable future: menggagas warisan peradaban bagi Anak cucu; seputar wacan pemikiran. Jakarta ICSD

Ida Nurlinda, 2009, Prinsip-prinsip Pembaharuan Agraria prespektif hukum, jakarta, PT Raja Grafindo Persada

Maria S.W Sumardjono, 2001, Kebijakan Pertanahan, Antara regulasi dan implementasi, Jakarta,penerbit kompas

Muchsan, 2000, Sistem Pengawasan terhadap Perbutan Aparat Pemerintah dan Peradilan Tata Usaha Negara di Indonesia, Yogyakarta, liberty

Otong Rosadi, 2012, Pertambangan dan kehutanan dalam perspektif cita hukum pancasila, yogyakarta, Thafa media.

Satjipto Rahardjo, 2010, Sosiologi Hukum Perkembangan Metode dan Pilihan Masalah, Yogyakarta, Genta Publishing

Soerjono Soekanto, 1981, fungsi hukum dan perubahan sosial, Bandung, Alumni

Soetandyo Wignjosoebroto, 1995, Dari Hukum Kolonial ke Hukum Nasional: Dinamika Sosial-Politik dalam Perkembangan Hukum Di Indonesia, jakarta PT Raja Grafindo Persada

Wahjono, 1986, Indonesia adalah negara berdasarkan atas hukum, Jakarta, ghalia Indonesia 